\title{
Reproducción y excedente económico. Aproximación teórica al estudio de los sistemas económicos
}

\author{
Claudio Fernández Macor \\ Universidad Nacional Del Litoral-Instituto de \\ Investigación Estado Territorio y Economía (IIETE)
}

Palabras clave

- Reproducción económica

- Excedente económico

- Sistema económico

\section{Resumen}

En el trabajo adoptamos el enfoque de la reproducción y excedente económico, creyendo que es una forma satisfactoria de abordar de manera científica y sistemática los rasgos estructurales y dinámicos de todo sistema económico. Teniendo en cuenta que todo sistema social está compuesto y conformado por diferentes subsistemas, a partir de nuestro enfoque, y sin pretender ser deterministas, también podremos inferir una serie características que exceden el sistema económico pero están notablemente influidos y en continua interacción con este.
Abstract
On this paper we take the reproduction and economic surplus approach. We believe it is efficient to address the structural and dynamic features of an economic system in a scientific and systematic way. Since every social system is composed of subsystems, from our approach, and without trying to be deterministic, we can also derive several features that exceed the economic system but are significantly influenced by it and continuously interacting.

Key words

- Economic reproduction

- Economic surplus

- Economic system 